\title{
Europeanization of Attitudes Towards Homosexuality: Exploring the Role of Education in the Transnational Diffusion of Values
}

\author{
Koen Slootmaeckers ${ }^{1,2} \&$ Conor O'Dwyer ${ }^{3}$ \\ 1 Department of International Politics, City, University of London, London, United Kingdom \\ ${ }^{2}$ Leuven International and European Studies (LINES), KU Leuven - University of Leuven, Leuven, \\ Belgium
}

${ }^{3}$ Department of Political Science, University of Florida, Gainesville, United States of America

Koen Slootmaeckers, Department of International Politics, City, University of London, Northampton Square, London, EC1V 0HB, United Kingdom. Email: Koen.slootmaeckers@city.ac.uk, Twitter: @kslootmaeckers, ORCID: 0000-0002-1189-5095

Koen Slootmaeckers is a Lecturer in International Politics at the Department of International Politics at City, University of London. His research focuses on sexuality politics in Europe. He is the editor of the volume EU Enlargement and Gay Politics: The Impact of Eastern Enlargement on Rights, Activism, and Prejudice (with Heleen Touquet and Peter Vermeersch; Palgrave 2016). Koen Slootmaeckers is also an affiliated researcher at Leuven International and European Studies (LINES) at the University of Leuven.

Conor O’Dwyer is Associate Professor of Political Science at the University of Florida. 


\section{Europeanization of Attitudes Towards Homosexuality: Exploring the Role of Education in the Transnational Diffusion of Values}

How does exposure to EU integration affect social attitudes in third countries, and what is the role of education in this process? These questions matter because the EU aspires to be not only a regulatory regime but also a community of values. Addressing both the common elision of attitudes and the underappreciation of education in Europeanization research, this article analyses the EU's impact on attitudes towards homosexuality in third countries via national education systems. This article offers not only an exposition of how we can expand our theoretical framework to include the transmission of values; its empirical findings demonstrate the need for this exercise, as some of the literature's underlying assumptions are shown to be unsupported.

Keywords: Europeanization; social learning; education; attitudes toward homosexuality; socialization; LGBT

\section{Introduction}

How does exposure to EU integration affect social attitudes in third countries? Do processes of Europeanization via enlargement contribute primarily to policy change, or do they also reshape the societal norms and beliefs underlying policy? Is this normative change process primarily an elite socialization process driven by participation in transnational policy networks and other EU-level epistemic communities - as the extant European literature generally suggests? Or is there a component of attitudinal change that occurs at the mass level and that is mediated by national education systems?

These questions are critical because the EU defines itself as more than just an economic community. ${ }^{1}$ As former Commission President José Manuel Barroso (2013) declared, 'Europe is above all and fundamentally a community of values.' These aspects of what the EU now considers its core identity have been codified in the EU Treaties: Article 2 of the Treaty on the European Union (TEU) defines the EU in terms of founding values, and Article 3 expresses the commitment to promote these values in its foreign relations. The EU's external relations, including trade agreements and development partnerships, and the Enlargement and Neighborhood processes are two oft-mentioned ways in which the EU promotes its values at the international and elite level. As is increasingly clear, however, the EU seeks to go beyond elite- 
level impact and to actively change 'hearts and minds', and education has taken on an important function in this regard. In the wake of recent terrorist attacks, the 2015 Paris Declaration of European education ministers emphasized education's central role in combatting extremism, promoting the EU's fundamental values, and creating good European citizens. It identified an 'urgent need to cooperate and coordinate' in order to ensure that 'children and young people acquire social, civic and intercultural competences, by promoting democratic values and fundamental rights, social inclusion and non-discrimination, as well as active citizenship' (European Council 2015, 4). Similarly, in January 2016 the European Parliament adopted the Ward Report on the promotion of fundamental EU values through intercultural dialogue, cultural diversity, and education (Ward 2015). Significantly, this report reflected not only on the role of education within the EU but also highlighted the need to include cultural dimensions (and thus education) within the work of the European External Action Service and EU representations throughout the world.

Within the EU, education is increasingly shaped by the EU's "soft law." While education remains mostly a national competence, the EU's Open Method of Coordination (OMC) has become 'a powerful strategy for shaping the education policy space around "learning" since it aims to achieve common objectives in particular areas of education' (Alexiadou, Fink-Hafner and Lange 2010, 346). Although the OMC is not concerned with issues of national identity formation per se, the EU has been trying to construct a sense of European identity (see e.g. Article 151, TEU), an identity which is closely connected to human-rights principles. Although some of these mechanism and initiatives are primarily aimed at EU member states they have spill-overs to the EU engagement with third countries, particularly as part of the enlargement process. Although candidate countries are not a formal part of the OMC, as a soft law instrument the OMC has an indirect impact on candidate countries because they are expected to adopt EU standards, be they constructed through hard or soft law. Another important process in this regard is the Bologna process that seeks harmonize the architecture of the European higher education system with the aim to establish a European Higher Education Area. Although this process goes 
beyond the EU and involves all the member states of the Council of Europe, the role of the European Commission in this process cannot be understated, as the Commission did not only have a strong hand in how the process unfolded but also in defining that the function of education is to create more democratic citizens (Keeling 2006).

Education policy is also more formally bound up with the enlargement process, as the EU accession negotiations include of a specific chapter dealing with Education and Culture (Chapter 26). Moreover, candidate countries are included within the Eurydice network, which supports and facilitates cooperation in the field of education. We would also note the existence of specific EU-led programs aimed at increasing cooperation between the educational systems of member states and third countries in order to modernize curricula (e.g. Education \& Training 2010 program, TEMPUS program).

The observation that the EU sees itself as a community of values and seeks to promote its fundamental values externally via education, amongst other means, inspired our starting questions regarding the links between education and societal attitudes during the process of EU enlargement. First, if the enlargement of the EU is a vehicle for diffusing EU values to applicant states, does education amplify this effect? Second, is education's influence more substantial before a state joins the EU or after it has done so? Third, what is the nature of Education's influence on societal attitudes? Is it indeed a socializer and transmitter of European values?

EU enlargement has been claimed to be 'the most successful democracy promotion policy ever implemented by an external actor' (Vachudova 2014, 122). Given such assessments, it is the more surprising that Europeanization scholars have not engaged with the socialization of EU values in a meaningful way (Dimitrova 2010; Sasse 2008), nor with the potential role of education within this process. Though vast, the Europeanization literature has focused on a rather narrow understanding of the EU's impact on domestic politics, orienting itself toward changes in public policy, not in values and attitudes. With its implicit assumption that formal compliance with EU rules and adoption of institutions eventually leads to social change, this legalistic focus potentially overestimates the 'EU effect' and ignores broader processes of social 
change. While perhaps of little practical consequence in policy areas not involving the public, for areas that involve both elites and publics this elision is problematic. Similarly, while there has been scholarly interest in the Europeanization of education within the EU, the role of education in the promotion of fundamental values beyond the EU's borders has not yet been systematically examined.

Identifying these lacunae in the literature, this paper offers an exposition of potential ways in which scholars of 'Europeanization-via-enlargement' can expand their theoretical framework and empirical focus to include the EU's impact on social attitudes. In particular, we explore the potential of education as a new avenue to analyze the transformation of attitudes within the Europeanization research agenda. Attitudes are an unconventional, yet theoretically relevant, measure of Europeanization outcomes. They provide a more direct measure of the extent to which Europeanization builds a community of values, in addition to a common policy regime. We seek to provide initial avenues to study the Europeanization of attitudes ${ }^{2}$ by recognizing the sociological literature which has repeatedly drawn attention to the socializing function of education and use these ideas to include the role of education in a more explicit fashion than is typical in the Europeanization literature. This perspective broadens the current understanding of Europeanization away from an elite-focused process towards a more 'everyday' conceptualization of Europeanization that relates to and investigates how the European integration process affects citizens, their political behavior, and attitudes. Indeed, we offer a first attempt to extend the as-yet underdeveloped theorization of social learning in nonmember-states. Moving beyond the elite-level, we draw attention to national socialization systems, especially education, as an indirect pathway through which the Europeanization of attitudes can occur. Here, we find that, contrary to the literature's methodological bias toward policy outcomes, social attitudes are also influenced by Europeanization processes, and that there is an important role for the educational system within the process.

We explore the potential of including education in the Europeanization of attitudes through a comparative study of attitudes toward homosexuality in 28 European societies (those 
countries not part of the EU prior to 2004). Lesbian, gay, bisexual, and transgender (LGBT) ${ }^{3}$ issues offer a revealing lens on the adoption of European values at the societal level. First, safeguarding LGBT rights - especially freedom from discrimination - has emerged as a core EU norm in recent years (Ayoub and Paternotte 2014; Slootmaeckers and Touquet 2016; van der Vleuten 2014). Second, it is by nature a policy area that requires a firm basis in prevailing social attitudes if it is to have practical effect. Without such a basis, there is a real possibility of pseudo-Europeanization, i.e. the adoption of legal norms for the sake of appearances (Dimitrova 2010). Despite these considerations, studies of the societal basis for LGBT policies have not yet found their way into either the literature on Europeanization or that on the transnational politics of gay rights (see e.g. Ames 2004; Langenkamp 2003, for exceptions see Ayoub 2016; Zapryanova and Surzhko-Harned 2016).

Thus, besides contributing to Europeanization's social learning theory by moving beyond the elite level, our study also adds to the burgeoning sociological literature on the political determinants of attitudes toward homosexuality (Adamczyk and Pitt 2009; Andersen and Fetner 2008; Gerhards 2010). ${ }^{4}$ As the literature on attitudes toward homosexuality has been predominantly concerned with individual-level factors (e.g. Finlay and Walther 2003; Herek 2007; Sears 1997; Slootmaeckers and Lievens 2014), our inclusion of national and supranational effects further positions this study on unexplored territory at the intersection of several well-developed literatures: we combine attention to the mechanisms of external influence identified in Europeanization theory with the quantitative methodology employed by the sociological literature on attitudes towards homosexuality.

In the next section, we review the Europeanization-via-enlargement literature to show how it may be refined to address the EU's impact on attitudes. We will demonstrate 1) that rational choice institutionalist theories of Europeanization do not provide sufficient grounding to analyze the EU's effect on attitudes, 2) that despite bringing in notion of socialization, the sociological institutionalist theories also fall short when it comes to analyzing attitudes. Based on this and the well-established sociological literature on the linkages between education and 
attitudes, we explore the potential of a new research agenda that studies national education systems as indirect pathway through which Europeanization can have an influence on individuals' attitudes. The following section presents our attitudinal data from a range of countries at different levels of Europeanization we will use to explore the potential of this proposed research agenda. The empirical analysis and results follow. We conclude by discussing our findings' implications and how it contributes to new research avenues on the Europeanization of attitudes which will have to explore the causal mechanisms of the educational pathway of Europeanization is explored in more detail.

\section{Integrating Attitudes and Education in the Europeanization theory: Three hypotheses}

In scholarly debates Europeanization knows many usages and refers to a variety of processes and mechanisms (Olsen 2002). To simplify the concept, we can divide understandings of Europeanization into two processes: (1) the building of the EU and European institutions, and (2) the diffusion of EU policies, norms, and values to other countries (Bulmer 2007). We are interested here in the latter and, following Radaelli's oft-cited formulation, define such Europeanization as,

processes of (a) construction, (b) diffusion, and (c) institutionalization of formal and informal rules, procedures, policy paradigms, styles, 'ways of doing', and shared beliefs and norms which are first defined and consolidated in the EU policy process and then incorporated in the logic of domestic (national and subnational) discourse, political structures, and public policies. (Radaelli 2003, 30)

Apart from the fact that this definition opens the door for a single framework to explore Europeanization across Europe by not limiting the process to any particular type of country, one other element bears special emphasis. By referring to the soft transfer of 'styles, "ways of 
doing", and shared beliefs and norms,' this definition does not reduce the impact of Europeanization (via enlargement) to mere legal transformations. In our reading, it in fact invites a broader conception of Europeanization which includes not only political but also societal values and norms. For our purposes, it justifies an analysis of Europeanization via enlargement that actively explores education's role in forming attitudes, norms, and ways of doing.

Europeanization (especially via enlargement) has been of interest to many scholars; the literature on the topic is already vast and still growing (e.g. Dobre 2003; Galbreath 2003; Glenn 2004; Grabbe 2006; Haughton 2007; Kelley 2006; Kochenov 2008; Langenkamp 2003; O'Dwyer 2010, 2012; Rechel 2008; Schimmelfennig and Sedelmeier, 2004, 2005; Vermeersch 2007). The question 'why third countries adopt and comply with EU policies and rules?' is typically answered via a rational choice institutionalism (RCI) or a sociological institutionalism (SI) perspective (Börzel and Risse 2003; Grabbe 2006; Schimmelfennig and Sedelmeier 2005). While both approaches identify the adaptational pressure created by degree of (mis)fit between European and domestic policies, processes, and institutions as the driver of Europeanization, they describe different causal mechanisms of domestic change (Börzel and Risse 2003, 2007; Bulmer 2007; Schimmelfennig and Sedelmeier 2005). ${ }^{5}$ In spite of their institutional and elite focus, we seek to explore the potential implications of both theoretical approaches for attitudinal change, particularly as these implications have been left unexplored empirically. Therefore, in our synopses of the RCI and SI approaches, we also reflect on the implications for social attitudes and the analytical potential of education.

The RCI perspective posits that a 'government adopts EU rules if the benefits of EU rewards exceed the domestic adoption costs' (Schimmelfennig and Sedelmeier 2005, 12). The adaptive pressures of EU accession alter the cost-benefit analysis of governments either by external incentives created by the EU (e.g. the conditionality principle) ${ }^{6}$ or by creating new opportunities and constraints for domestic actors to pursue their interests (Börzel and Risse 2003; Schimmelfennig and Sedelmeier 2005). For example, by applying conditionality the EU 
incentivizes third countries to comply with membership criteria: it rewards compliance with the upgrading of institutional relations (e.g. granting visa free travel, granting candidate status, opening negotiations, and ultimately EU membership), and it withholds these rewards when countries fail to comply (Schimmelfennig and Sedelmeier 2005, 11). This is a top-down and instrumental view of Europeanization that, like traditional rational-choice approaches, takes preferences (and attitudes) as exogenous and fixed. There is little room for considering attitudinal shifts or for including education in this approach, not only theoretically but also empirically. Indeed, empirical research on, for example the Europeanization of minority policies (Dobre 2003; Galbreath 2003; Kelley 2006; Rechel 2008; Vermeersch 2005), has consistently found that while the candidate countries did adopt minority legislation under EU pressure, these EU rules did not penetrate the new member states beyond formal compliance. 'Talking the talk' was enough to convince the EU of compliance (Haughton 2007, for similar results on LGBT rights see Ames 2004; Kochenov 2006; Langenkamp 2003; O'Dwyer 2010, 2012; Slootmaeckers and Touquet 2016). Research on the Europeanization of LGBT rights has demonstrated that whilst the enlargement process was able to create legal change, its immediate effect on norms and the behaviour of political elites was disappointing (O'Dwyer and Schwartz 2010). Political and state-sponsored homophobia remains disturbingly widespread in the new member states (Davydova 2012; Graff 2006; Kuhar and Takács 2007; Rédai 2012), and, in some instances, even led to legal backlashes (Slootmaeckers and Touquet 2016). In short, whereas the theory might not consider attitudes, the empirical findings have also demonstrated that the conditionality principle remains unable to sufficiently address public attitudes (Nancheva 2007; Rechel 2008). Enlargement has been described as a top-down, elite driven process with little societal re-adjustment (Galbreath 2003), and as such there is little reason to believe that external incentives will contribute to attitudinal change, at least at the broader societal level. Thus, we hypothesize no effect of conditionality on attitudes (H1). ${ }^{7}$

Sociological institutionalism-or social learning theory, as it is often called within this literature-offers a more hospitable framework for incorporating attitudes into 
Europeanization processes, even if, as we argue below, it has tended to be downplayed in extant studies of EU enlargement's effect on domestic politics. Social learning theory engages with the 'soft transfer' of EU rules (Vermeersch 2005). With roots in social constructivism, this approach deals in the realm of ideas, culture, and political psychology (Börzel and Risse 2003; Bulmer 2007; Checkel 2001; Schimmelfennig and Sedelmeier 2005). The core premise is that governments adopt EU norms when they are persuaded of their appropriateness. Thus, the EU can be conceptualized as a formal institution representing a wider community, defined by shared beliefs, values, and collective identity (Schimmelfennig and Sedelmeier 2005, 18). With regard to third countries, the EU is seen as a teacher of norms that through processes of socialization and persuasion ${ }^{8}$ tries to create a larger 'norm ownership' and to persuade third countries to redefine their interests and identities (Börzel and Risse 2003). ${ }^{9}$ Europeanization via enlargement, then, is understood in the literature as the emergence of new rules, norms, practices and meaning, which third states incorporate into their domestic structures via processes of social learning (Börzel and Risse 2007). Compliance presupposes that a country's civil society actors and political elites internalize the beliefs, norms, and values constituting the European community, and that governments consequently adopt EU rules because they deem them appropriate in terms of their collective identity, values and norms (Schimmelfennig and Sedelmeier 2005).

While the SI approach refers to identities, values and norms, the absence of public attitudes in the extant empirical work is notable - as is, for that matter, the absence of education in its theorizing. Although scholars increasingly recognize that 'the concentration on formal measures, such as legal change, offers at best a very thin notion of conditionality effects' (Sasse 2008, 855), most studies focus on 'hard' rules rather than on 'soft' ones because the former are straightforward to operationalize (Dimitrova 2010,138). They are written down and subject to outside enforcement, whereas the latter are not. When they are made the subject of research, soft norms are typically identified in terms of 'rules-in-use,' as opposed to written rules (Ostrom 1999, 36-37), or they are operationalized as the 'creation of supporting and 
supplemental rules' (Dimitrova 2010,139). Alternatively, studies engage in the analysis of case studies through process tracing and thick description of politics on the ground. A good example is Vachudova's $(2005,2008)$ research on how EU accession affected liberal democratic norms and party competition in several East European accession states. Although these efforts do capture the soft impact of the EU, they still suffer from a bias towards the public policy and hard norms. Training attention back on attitudes, then, is our main contribution to the Europeanization literature.

Whilst the impact of conditionality has been a consistent feature of extant empirical research, evidence that social learning occurs during the enlargement process has remained rather limited (Dimitrova 2010; Kelley 2006; O'Dwyer 2010; Sasse 2008; Vachudova 2005). Although we believe this lack of empirical support is partly due to the scholarship's almost single-minded focus on the external incentives model, and particularly on conditionality, Krizsan and Popa (2010) have made a compelling argument that this discrepancy in empirical evidence for the RCI and SI models of change is mainly due to the temporal ordering of these processes: while external incentives channels, and conditionality in particular, are the dominant drivers of Europeanization during the pre-accession period, social learning occurs predominantly after accession. Based on this argument, and following sociological structuralism's axiom that 'individuals who are part of the same social unit and/or influenced by the same structural characteristics develop [...] a more or less similar behavioral pattern' (Brutsaert 1995, 64, translated by authors), we hypothesize that people living in an EU member state for a (longer) period of time will, ceteris paribus, have more positive attitudes toward homosexuality (H2). Such individuals are thus hypothesized to take on the EU's constitutive values and associated progressive attitudes, including tolerance for homosexuality. They do so as a result of being part of the political union and the values it represents. This hypothesis is based on the previously mentioned assumption in the Europeanization literature that, over time, institutional change will be followed by societal change. As such, whether we find support for this hypothesis has implications for the wider 
Europeanization literature. Indeed, failing to find support for this hypothesis would not only provide evidence for our argument that studying attitudes as an outcome of Europeanisation matters but also that we cannot conceptualise Europeanization of fundamental rights and values without actively theorizing and investigating social change. Similarly, in terms of policies, such a result would make clear that the EU needs to engage with more pro-active approaches to social change in candidate countries or its efforts might not yield the desired outcomes.

Although the dominant view in the Europeanization literature is that social learning occurs primarily after accession, a few studies have found evidence of social learning during the accession process (e.g. Andonova 2005). These studies invariably stress that social learning complements and coexists with external incentives. Typically, the agents of interest here are at the elite level: 'trans-European nongovernmental networks among both industry and advocacy organizations' (Andonova 2005, 139) and 'legal advisors acting as an epistemic community' (Schwellnus 2005, 70). Others have suggested, but never deeply analyzed, that social learning also impacts the general population during the pre-accession process (Schimmelfennig and Sedelmeier 2005). In trying to bring in public opinion as an outcome of Europeanization processes, we cannot ignore the not-small irony that the social learning literature remains rather vague about schooling and the role of schooling systems. Typically, it deals more with the socialization of political elites (often transnationally) than it does with general publics through national education systems. Yet, education systems are one of the most important socialization agents in modern society (Meyer 1977; Sigel 1965). It has long been established in sociological literature that formal schooling contribute to political socialization, i.e. 'the gradual learning of the norms, attitudes, and behavior accepted and practiced by the ongoing political system' (Sigel 1965, 2, our emphasis). The educational system thus provides individuals with experiences that foster knowledge, skills, attitudes, and values that are compatible with the current political system (Meyer 1977). Similarly, Inglehart (1970) has argued that education is an indicator of cognitive mobilization, which he argues leads to an 
increased capacity to relate 'to remote roles and situations' and thus enables people to better 'receive and interpret messages relating to a remote political community' (Inglehart 1970, 47).

If we are speaking of the impact of transnational norms on the attitudes of the general public, then a likely instrument and locus of any such attitudinal change will be the national education system. Although the nation-state remains responsible for its educational institutions and policies, the literature on globalization of educational policy clearly demonstrates that nation states, their societies and education system are 'embedded in, and influenced by, their wider context' (Ramirez, Meyer and Lerch 2016, 43). Within the world culture theory, it has been argued that countries and their institutions tend to become isomorphic with global standards and models of change (Meyer, Boli, Thomas and Ramirez 1997). Within this world society, there are 'multiple social engineering efforts [...] and the rise of common standards [..., which] tend to be justified by normative global standards like human rights' (Ramirez et al. 2016, 44). Within this type of system, which produces 'influential forms of governance without government' (Ramirez et al. 2016, 44) and in which education is a key avenue through which these standards are attained (Meyer et al. 1997), one can expect and observe an isomorphism of educational systems.

With the EU being perhaps the closest approximation to this kind of world society to date, and in light of the EU-level institutional and policy changes outlined in the introduction, we hypothesize that the EU contributes to the increased isomorphism of the educational systems of its member states as well as of neighboring countries. Further, we expect that as countries move closer to the political system of the EU during the European integration process, their education systems will increasingly promote and foster EU norms in society. Drawing parallels with the literatures on Euroscepticism and European identity (see e.g. Inglehart 1970; Lubbers and Scheepers 2007), which consistently demonstrate that more highly educated people align themselves more with Europe and its values, we expect that for countries in later stages of the European integration process the effect of education on attitudes will be stronger (H3). 
This hypothesis that education matters as an indirect pathway for the Europeanization of attitudes is based on two sociological theories on how education contributes to the socialization of tolerant attitudes (see Hagendoorn and Nekuee 1999). The first theory highlights the normative function of education, arguing that education teaches people democratic values (see e.g. Ohlander, Batalova and Treas 2005). Such normative socialization is said to have a lagged effect that remains long after people have graduated, as adults have the tendency to adopt the qualities and attitudes appropriate to the roles and expectations attributed to the more educated (Meyer 1977, 60). In other words, we hypothesize that education facilitates the Europeanization of attitudes because theory suggests that as a country moves closer to the EU, educational institutions will actively teach the so-called European values to pupils. Additionally, those who have left the educational system long before, are according to this theory, more likely to change their attitudes in order to conform to roles and expectations that are associated with being a highly-educated individual. The second theory on the role of education in democratic value formation stresses the cognitive function of education (Hagendoorn and Nekuee 1999; Ohlander, Batalova and Treas 2005). Education, in this view, provides individuals with the skills to interpret and be cognizant of the surrounding world, creating the ability to understand different perspective and realities, and therefore exhibit more tolerant attitudes. Hence, this theory helps to explain the hypothesized effect by proposing that when a country moves closer to the EU, those with greater educational attainment will be more likely to understand and internalize the constituent values of the EU irrespective of when they were educated. Although both theories provide different explanations and causal pathways for the effect of education, both support our hypothesis that this educational effect to hold when controlling for age. Or put differently, while this education effect should be most evident for the younger generation, who are currently enrolled in school, we expect it to hold for the older generations as well; either due to the previously mentioned lagged socializing effect of education or due to the cognitive effect of education which fosters the ability to critically analyze changing social environments. 
To summarize, based on the Europeanization literature and the sociological literature and education and socialization we formulate three hypotheses regarding conditionality and two on the social learning effects of Europeanization on individuals' attitudes towards homosexuality:

H1: No effect of conditionality on attittudes. Conditionality leads to the formal adoption of policies but not to a change in citizens' attitudes. The strength of conditionality that a country experiences does not affect the attitudes of its citizens towards homosexuality. H2: Attitudinal change after accession, through EU membership. The longer a country is an EU member state the more positive its citizens' attitudes towards homosexuality will be.

H3: The Europeanization process contributes to attitudinal change mediated by education. The effect of education will be stronger in countries increasingly enmeshed within the EU framework.

\section{Data and Measures}

We use attitudes toward homosexuality as an indicator of the diffusion of EU minority-rights norms via social learning, as mediated by education. We do so because of its saliency and its increased linkage with the EU's identity (see Ayoub and Paternotte, 2014), and because we consider it a hard case for our analysis as LGBT rights are more contentious then other discriminatory attitudes. This issue bridges the gap between public policy and value systems. ${ }^{10}$ Using the abundant available data on public attitudes towards homosexuality across countries and over time we gauge the impact of EU integration on public attitudes towards homosexuality. More specifically, we test our hypotheses using the Integrated Value Survey (IVS), a dataset combining the European Value Survey (EVS 2011) and the World Value Survey (WVS 2015). The IVS is a repeated cross-sectional survey conducted in 7 waves between 1981 
and 2014. As we are interested in attitudes towards homosexuality in those European countries that were not member of the EU prior to 2004, we selected 28 European countries from this master dataset. ${ }^{11}$ To ensure temporal comparability, we decided to only include data from the post-communist period (i.e. after 1989). The time frame was further restricted by the absence of a comparable measure for the educational level of respondents prior to 1995 . The final dataset includes repeated cross-sectional data from 28 countries over the time period 1995 2014 and is structured in three levels: individuals, within surveys, within countries. We have a total sample of 120982 individuals from 96 surveys in 28 countries.

\section{Measures}

Our dependent variable 'attitudes towards homosexuals' is operationalized in the IVS as the 'justification of homosexuality.' Respondents in all waves of the IVS were asked to respond to the question 'Please tell me for each of the following statements whether you think it can always be justified, never be justified, or something in between: homosexuality?' using a Likert scale ranging from 1 'never justifiable' to 10 'always justifiable.'

In addition to the main EU measures discussed below, we include control variables known to be correlated with attitudes towards homosexuality. At the individual level, we control for what Slootmaeckers and Lievens (2014) labeled the standard model of attitudes towards homosexuality: gender, age, education, religion. ${ }^{12}$ Gender is operationalized as a dummy variable with 'male' as the reference category. For education, we distinguish between eight categories based on the International Standard Classification of Education (ISCED) three digits classification and follow the principles of the CASMIN (Comparative Analysis of Social Mobility in Industrial Nations) coding: categories range from 'Inadequately completed elementary education' to 'University with degree/higher education - upper-level tertiary.' Following common practice, we treat this as a continuous variable in the analyses. ${ }^{13}$ To facilitate interpretation of the results, we center this variable on the value of 6 ('Complete secondary: university-preparatory type/full secondary'). ${ }^{14}$ Religion is measured as the denomination to 
which one belongs: 'No denomination' (reference category), 'Roman Catholic,' 'Protestant,' 'Orthodox,' 'Muslim,' and 'Other.' The last individual-level measure is 'religious practice,' or the frequency of attending religious services (Likert scale ranging from 1 'more than once a week' to 7 'never, practically never'). To ease interpretation of the results, we center this variable on the value of 4 ('attending religious service only on holy days'). The literature has shown that, all things being equal, women, younger individuals, and people with higher levels of education generally have more positive attitudes towards homosexuality than men, older, and lesseducated people. Regarding the religious measures, two effects are commonly found: religious denomination and religious practice. Individuals of greater religiosity are generally more negative towards homosexuality, regardless of their denomination.

Although conceptually country characteristics, we include the variables capturing Europeanization effects at the survey level since they vary over time within a country. As conditionality is very hard to quantify, we use a proxy to capture its effects. Following Börzel and Risse's (2012) argument that the EU's ability to enforce compliance among non-members becomes weaker when countries' institutional proximity to EU membership decreases, we operationalize conditionality as the accession status, i.e. the status in the EU integration process. Concretely, we distinguish four categories of institutional status: EU members; EU candidates or potential candidates; members of the European Neighborhood Policy (ENP); and 'permanent outsiders.' This operationalization constitutes a proxy for conditionality because it captures both the size and credibility of the incentives at different stages in the membership process. Countries with no membership prospects lack any incentive to adjust to EU norms, of course. Compared with the outsiders, countries participating in the ENP are offered the incentive of deepening relations with the EU in the future-though not an explicit offer of eventual membership. Because of the open-ended nature of this incentive, the credibility of EU threats for violating norms is comparatively low (cf. Schimmelfennig and Scholtz 2008). ${ }^{15}$ We expect conditionality to be stronger in states that have signed agreements with explicit provisions for future EU membership, i.e. the candidate and potential candidate states. In these states, we 
expect that, with a larger incentive (eventual full membership) at stake, both the scope of conditions and the credibility of sanctions for noncompliance will be greater. ${ }^{16}$ We would be the first to admit that there is room for small differences in the credibility of EU commitment across states in this category, but to try to capture these in our coding of conditionality would be to miss the real difference between states seeking membership, i.e. those with explicit vs. implicit promises of future integration. ${ }^{17}$ Finally, once a state actually joins the EU, it no longer faces conditionality as such; however, it now is legally obliged to comply with all EU legal norms, and failure to do so threatens its own set of sanctions through the Commission and courts. Recall that our first hypothesis states that we do not expect conditionality to influence attitudes; therefore, we would reject that hypothesis if we find robust differences between these four categories.

The second EU variable is the number of years a country has been a member of the EU (cf. attitudinal change after accession, H2). To test H3 we included a cross-level interaction between proximity to EU and educational level.

Finally, following Kuhar's (2013; see also Andersen and Fetner 2008) observation that religious tradition and post-socialist transition are the two (country-level) factors that predominantly shape attitudes towards homosexuality, we include both measures as controls at the country level. ${ }^{18}$ These effects are captured with two variables: a dummy indicating whether a country has a communist past and a set of dummies indicating its predominant religious tradition. For the latter, we draw on the work of Norris and Inglehart's (2004) and distinguish countries with a predominant Catholic, Protestant (reference category), Orthodox, and Muslim tradition.

\section{Analysis and Results}

Given the nature of the research question, we use a multilevel technique to explore the EU's effect on individuals' attitudes towards homosexuality. This technique allows us to study relations between variables at different levels taking into account the hierarchical structure of 
the data. For the analyses, we use the MLwiN software (v2.35; Rasbash et al. 2015). All coefficients presented below are estimated using a Full Information Maximum Likelihood logarithm, i.e. Iterated Generalized Least Squares (IGLS; Goldstein 2011).

The analyses are structured in 5 models of increasing complexity (see table 1). The first model is the null model. This model, with only a constant term, is used to calculate the intracountry and intra-survey correlations. These two measures capture the amount of variation in attitudes towards homosexuality that can be attributed to the second (survey) and third (country) levels. As shown in table 1, $28.0 \%$ of this variation can be attributed to the country level, $3.2 \%$ to the survey level, and the remaining $68.8 \%$ is situated at the individual level.

[Table 1: 'Results of the Multilevel Analyses' ABOUT HERE]

The second model includes the individual level variables. Our findings here are consistent with the literature (see model 2, table 1). Women, higher educated, non-religious, and younger people are generally more tolerant of homosexuality than men, less educated, religious (all denominations), and older individuals. We also find that those attending religious services less frequently have less negative attitudes towards homosexuals.

Models 3 and 4 are constructed by adding stepwise the wave- and country-level variables. In model 3 we test hypotheses $\mathrm{H} 1$ and $\mathrm{H} 2$ (cf. supra). Model 4 tests whether these effects hold after controlling for a country's communist past and religious heritage. Although introducing the EU variables (model 3, table 1), explains 4.5\% of the country level variation in attitudes towards homosexuality in the sample, this does not significantly contribute to a better understanding of attitudes towards homosexuality. Against the literature's tendency to view conditionality as the most effective EU foreign policy tool, we find no robust effect of accession status on attitudes toward homosexuality (H1 is supported). To recall our review of the Europeanization literature earlier, it would seem that, regarding minority rights at least, the assumption that EU conditionality induced policy change is connected to broader societal 
change is based more on faith than evidence. Similarly, we do not find a significant effect of years in the EU, which leads us to reject H2. The lack of evidence of the attitudinal change through simply being part of the EU might be due to the fact that only little time has elapsed since the first countries of our sample joined the EU. Indeed, when we run these analyses including the EU member states (results not reported), we do find a significant effect for years in the EU. It is important, however, to use caution when interpreting such results as causality cannot be established. Thus, although there might be a potential correlation between years in the EU and attitudes towards homosexuality when including old member states in the analysis, the existing data on non-EU15 European countries do not allow us to conclude that social change automatically happens after accession. Indeed, the possibility of political backlashes after accession may mean that attitudinal changes after accession will follow a non-linear trajectory. Thus, we find no evidence in support of $\mathrm{H} 2$, but to make a final judgement regarding the hypothesis, we believe more longitudinal data are required. Nevertheless, the lack of support for $\mathrm{H} 2$ raises important questions regarding the implicit assumption of the Europeanization literature which seemingly departs from the notion that institutional change will be followed by social change over time. If this assumption were to be true we would have found evidence in support of $\mathrm{H} 2$, therefore, our results strongly suggest more detailed research is needed into how the EU accession process can contribute to social change post-accession as such process is not a given.

The effects of the country-level control variables for religious heritage and communist past are very much in line with previous scholarship. We find that there is no difference between Catholic and Protestant countries. Citizens of both Orthodox and Muslim countries, on the other hand, are generally more negative towards homosexuality than their counterparts in Protestant countries. As expected, individuals living in a country with a communist past are in general more negative towards homosexuality than their counterparts in Western Europe.

Whereas we did not find evidence of the sociological structuralist interpretation of social learning, we do so for our more complex, indirect education-mediated model. To recall 
our earlier discussion, we hypothesize that as states' proximity to the EU system increases - i.e. as their status vis-à-vis membership changes and, thus, they become increasingly imbricated within its political system, norms, and 'ways of doing' - domestic socialization agents, especially schools, will increasingly socialize citizens in the norms and values of the EU. Thus, in model 5 (Table 1), we seek to identify such 'education-mediated impact of Europeanization' by employing a cross-level interaction between accession status and education (cf. H3). The results provide evidence in support of hypothesis H3, i.e. that there is a form of indirect impact on attitudes via education. Looking more closely at the interaction effect, we find that the baseline effect of education in the outsider category is modest $(b=0.091)$, but significantly increases with 0.034 for ENP countries and 0.053 for (potential) candidate countries. The additional effect of education for EU member states is 0.170 . This cross-level interaction effect is further illustrated in Figure 1.

[Figure 1 about here]

Analyzing the predicted values for this interaction effect, it becomes clear that we must remain cautious in interpreting the causal mechanisms behind these results. While we do indeed find that the effects of education are stronger in those countries closer to the EU and EU member states compared to the permanent outsiders, it would be too big a leap to interpret this as strong evidence that the normative function of education (i.e. the socializing of liberal norms) becomes stronger as countries move closer to the EU. In fact, the predicted values show a pattern that suggest that polarization across the educational divide on the issue of homosexuality increased in societies that are closer to the EU. In these countries, the lower educated layers of society are on average more inclined to maintain negative attitudes towards homosexuality, whereas the level of homonegativity remains relative stable for the higher educated citizens, i.e. there are only small differences in predicted values for different proximities to the EU. In other words, whilst the slope of the educational effect is indeed steeper 
for ENP and (potential) candidates, and EU member states compared to outsider countries (which might suggest an increased effect of the normative function of education), it has to be noted that the expected values for the lower educated in EU member states, ENP and (potential) candidate countries are lower than the expected values for this group in the outsider countries. This rather surprising discrepancy might indicate that it is not the normative function of educational socialization that is important, but rather the cognitive function of education, which gains importance when countries are involved in EU integration processes. Hence, we caution against the simplistic interpretation that education is a socializer or transmitter of liberal attitudes per se, but instead favor an interpretation which foregrounds that education contributes to development of liberal attitudes by providing people with the skills to critically evaluate and interpret the complexities of their social and political environment. Based on our findings and other research which observed the politicization of homosexuality as part of the EU enlargement process (see e.g. Mole 2011, 2016; O’Dwyer 2012; Renkin 2009; Slootmaeckers and Sircar 2018), it could be suggested that education rather acts as a buffer for the more educated groups of society against politics which rely on othering and prejudices against outgroups (illustrating the importance of the normative function of education). However, whilst such interpretation seems to be supported by the presented and existing research, our analysis does not allow us to make any final statements on how education contributes to the promotion of so-called European values. Our results do, however, raise important questions and open up new and as of yet unexplored avenues for future research.

In sum, the interaction shows us that the education effect strengthens countries become increasingly enmeshed within the EU framework. While this effect indicates that social change can occur during the EU accession process (or ENP process), it also highlights that such processes are mediated by education and cannot be operationalized as a merely a result of EU membership (cf. H2). Although our results clearly indicated the value of including education in our theorizing of the transnational diffusion of attitudes, there is still much to be said about what causal mechanism are at play. Although we have provided some initial pathways of 
interpreting the role of education within the EU integration process, we see our results as a starting point for more discussions about and research into the role of education within international political processes of norm diffusion. More research is needed to analyze whether education acts as a socializer of fundamental values, as a buffer against the instrumentalization of morality issues for certain political goals, or perhaps, as suggested by our results, that the EU enlargement process reinforces the social stratification based on education.

\section{Conclusion}

This paper was motivated by two lacunae in the related yet separate literatures of Europeanization-via-enlargement and Europeanization of education. First, whilst the Europeanization-via-enlargement literature has recognized that the EU enlargement process seeks to promote EU values to third countries, it has paid insufficient attention to the societal impacts of these processes. This elision may have little practical consequences for more technocratic policy areas, but it appears problematic for those issues that go beyond the public policy realm and involve both elites and publics. This is the case for LGBT rights. To be effective, legislative changes in this field must have a firm basis in social attitudes. Second, whilst there is an increasing literature on the Europeanization of education, this scholarship has predominantly focused on the creation of a European education sphere and has paid little attention to education's role in the promotion of fundamental values. With these lacunae in mind, we have explored the Europeanization of attitudes towards homosexuality and education's role in this process.

Attitudes are an unconventional, yet theoretically relevant, measure of Europeanization outcomes. They provide a more direct indicator of the extent to which Europeanization is about building a community of values as opposed to a common policy regime. Attitudes are also closely related to education, and our investigation of attitudinal change here allows us to include the role of education in a more explicit, albeit also exploratory, fashion than is typical in 
the Europeanization literature. Doing so not only promotes a conversation between the fields of Europeanization-via-enlargement and the Europeanization of education, it also broadens the current understanding of Europeanization away from an elite-focused process towards a more 'everyday' conceptualization of Europeanization that relates to and investigates how the European integration process affects citizens, their political behavior, and their attitudes.

Our empirical findings present important challenges to some of the Europeanization literature's underlying assumptions. First, we find that public attitudes towards homosexuality are unaffected by the strength of the conditionality that a country experiences. After controlling for both individual- and country-level characteristics, we do not find a statistically significant difference between the attitudes of individuals living in outsider countries, on the one hand, and those living in ENP, (potential) candidate countries, and EU member states, on the other. Thus, while the EU can make countries comply with EU legislation, including policies toward LGBT people, we do not find evidence that these changes penetrate into society. Second, we do not find evidence of social change simply by virtue of being a member of the EU - i.e. people living in countries that are part of the EU for a longer period of time do not have more positive attitudes towards homosexuality. These two findings are important as they challenge the oft-implicit assumption with the Europeanization literature that formal compliance will eventually lead to social change.

Consequently, when theorizing about the social impact of the EU, we need to go beyond institutions and consider different pathways through which the EU can contribute to social change. In order to start such research agenda, we have explored the potential of including education in the analysis of Europeanization of attitudes. Our analysis lead to two important findings regarding the Europeanization of attitudes. First, we find evidence of 'social learning' after accession via education. Second, we find evidence of social learning prior to accession and in countries not part of the enlargement strategy. Agreeing with the few studies that found social learning effects prior to accession (see Andonova 2005), we view socialization through education as a process that complements and coexists with the institutional European 
integration process (i.e. conditionality). We have argued that to gauge the impact of the EU's promotion of fundamental values beyond the elite level, we have to extend the theorization of the so-called 'soft' Europeanization mechanisms. We have suggested including domestic socialization agents like educational institutions as an indirect pathway through which the Europeanization process can affect attitudes, an argument strongly supported by our data. Indeed, we found that the effects of education are stronger in countries that are closer to the EU. Yet, our results do not provide definite answers as to how education contributed to these attitudes, but rather raise important questions about and provide new avenues for future research on the mechanisms though which education works in the diffusion of values in political integration processes. In other words, although our analysis is not able to provide the final answer to many of the questions raised, it does highlight important elisions in the existing literatures and provides a response to these in the form of a new research agenda within the Europeanisation literature that will not only take social change and attitudes more seriously but that also theorizes how education can play a role in these processes.

An important question raised by our findings is whether it is possible that education mediates the effect of accession on social attitudes in less straightforward ways than diffusing progressive values; for example, may it serve to reinforce social stratification's effects on attitudes, serving as a buffer for the more educated against politics that rely on othering and prejudices against outgroups? If the latter is indeed the case, we should no longer be speaking of the EU as a teacher of norms or speak about the Europeanization process in a way where the EU is introducing new norms to candidate countries. Instead a more critical approach may be needed where the Europeanisation process is conceptualized as a normative struggle (see Slootmaeckers, 2017) not only at the political level, but also at the social level where the higher educated are more inclined to align themselves with the progressive values the EU calls its constitutive base, whereas the lower educated people are more vulnerable for those politics which thrive on the resistance of these values. 
The finding that the EU's impact on societies is more complex and less positive than perhaps hoped for has also important implications for the EU's policies and approaches to the EU Enlargement process. If the EU is committed to building a community of values that goes beyond a common policy regime and wants to counter the stratifying effect it currently has, it will have to rethink its approach to Europeanization to complement its conditionality principle with active measures that promote social change. The publics of the candidate countries will have to be foregrounded in its policies. In particular, the EU enlargement process and the EU commission should adopt policies that seek to improve the social position of those at the losing end of globalization processes and the recent economic crises - often those with lower education levels - so that they become more resilient to the political maneuvers of conservative forces that seek to build political capital through exclusionary politics that reinforce heteronormative and patriarchal societal values.

In sum, based on our findings, we argue that we need to move away from merely institutionalist analyses of EU Enlargement. As such, we call for more theorization of the complex ways in which social attitudes are shaped by the Europeanization process. We particularly emphasize the particular role played by education within the international promotion of norms and values. Although the last word has not been said about the ways in which education can contribute to the Europeanization process itself and associated process of social change. As our initial findings are unable to find support for the oft-implicit assumptions of the Europeanization literature (and even of the EU's approach to enlargement) and as such we argue that there is a need to rethink how we approach to analysis of the Europeanization process to move being institutions and public policy as social change cannot be expected to happen over time. Moreover, we also argue for a more cautious and critical approach to the role of the EU within the process as it might not the source of good it is often imagined to be. In fact, when it comes to societal attitudes, the EU accession process might have the unintended consequence of reinforcing societal stratifications rather than promoting social change. 


\section{References}

Adamczyk, A., and C. Pitt. 2009. "Shaping attitudes about homosexuality: The role of religion and cultural context.” Social Science Research 38 (2): 338-351.

Alexiadou, N., D. Fink-Hafner, and B. Lange. 2010. "Education Policy Convergence through the Open Method of Coordination: theoretical reflections and implementation in 'old' and 'new' national contexts." European Educational Research Journal 9 (3): 345-358.

Ames, L. M. 2004. "Beyond Gay Paree: What does the enlargement of the European Union mean for same-sex partners." Emory International Law Review, 18: 503-554.

Andersen, R., and T. Fetner. 2008. "Cohort differences in tolerance of homosexuality: Attitudinal change in Canada and the United States, 1981-2000." Public Opinion Quarterly 72 (2): 311-330.

Andonova, L. B. 2005. "The Europeanization of Environmental Policy in Central and Eastern Europe." In The Europeanization of Central and Eastern Europe, edited by F. Schimmelfennig and U. Sedelmeier, 135-155. Ithaca (New York), USA: Cornell University Press.

Ayoub, P. M. 2014. "With Arms Wide Shut: Threat Perception, Norm Reception, and Mobilized Resistance to LGBT Rights." Journal of Human Rights 13 (3): 337-62.

Ayoub, Phillip M. 2016. When States Come Out: Europe's Sexual Minorities and the Politics of Visibility. New York: Cambridge University Press.

Ayoub, P. M, and D. Paternotte, eds. 2014. LGBT Activism and the Making of Europe: A Rainbow Europe? Basingstoke: Palgrave Macmillan.

Barroso, J. M. 2013. “\#Europe Is Above All and Fundamentally a Community of Values.” Twitter. November 5. https://twitter.com/JMDBarroso/status/397786886166822912.

Börzel, T. A, and T. Risse. 2003. "Conceptualizing the Domestic Impact of Europe." In The Politics of Europeanization, edited by K. Featherstone and C. M. Radaelli, 57-80. Oxford: Oxford University Press.

Börzel, T. A, and T. Risse. 2007. "Europeanization: The Domestic Impact of EU Politics." In Handbook of European Union Politics, edited by K. E. Jørgensen, M. Pollack, and B. Rosamond, 483-504. London: SAGE.

Börzel, T. A, and T. Risse. 2012. "From Europeanisation to Diffusion: Introduction." West European Politics 35 (1): 1-19.

Brutsaert, H. 1995. Sociologie [Sociology]. Gent: Universiteit Gent Vakgroep Sociologie.

Bulmer, S. 2007. “Theorizing Europeanization." In Europeanization: New Research Agendas, edited by P. Graziano and M. Vink, 46-58. Basingstoke: Palgrave.

Checkel, J. T. 2001. "Why Comply? Social Learning and European Identity Change." International Organization 55 (3): 553-588.

Davydova, D. 2012. "Baltic Pride 2010: Articulating Sexual Difference and Heteronormative Nationalism in Contemporary Lithuania." Sextures 2 (2): 32-46.

Dimitrova, A. L. 2010. "The New Member States of the EU in the Aftermath of Enlargement: Do New European Rules Remain Empty Shells?" Journal of European Public Policy 17 (1): 137-148.

Dobre, A.-M. 2003. "EU Conditionality Building and Romanian Minority Rights Policy: Towards the Europeanization of the Candidate Countries." Perspectives on European Politics and Society 4 (1): 55-83. 
European Council. 2015. Declaration on Promoting citizenship and the common values of freedom, tolerance and non-discrimination through education. Paris: European Council

EVS (European Values Study). 2011. European Values Study 1981-2008, Longitudinal Data File. Cologne, Germany: GESIS Data Archive.

Finlay, B., and C. S. Walther. 2003. "The Relation of Religious Affiliation, Service Attendance, and Other Factors to Homophobic Attitudes Among University Students." Review of Religious Research 44 (4): 370-393.

Galbreath, D. 2003. "The Politics of European Integration and Minority Rights in Estonia and Latvia." Perspectives on European Politics and Society 4 (1): 35-53.

Gerhards, J. 2010. "Non-Discrimination Towards Homosexuality: the European Union's Policy and Citizens' Attitudes Towards Homosexuality in 27 European Countries." International Sociology 25 (1): 5-28.

Glenn, J. K. 2004. "From Nation-States to Member States: Accession Negotiations as an Instrument of Europeanization." Comparative European Politics 2 (1): 3-28.

Glüpker, G. 2013. "Effectiveness of EU Conditionality in the Western Balkans: Minority Rights and the Fight Against Corruption in Croatia and Macedonia." Journal of Contemporary European Research 9 (2): 223-241.

Goldstein, H. 2011. Multilevel Statistical Models. 4th ed. Sussex: Wiley.

Grabbe, H. 2006. The EU Transformative Power: Europeanization Through Conditionality in Central and Eastern Europe. New York: Palgrave Macmillan.

Graff, Agnieszka. 2006. "We Are (Not All) Homophobes: A Report from Poland." Feminist Studies 32 (2): 434-449.

Hagendoorn, A., and S. Nekuee, eds. 1999. Education and racism: A cross national inventory of positive effects of education on ethnic tolerance. Aldershot: Ashgate.

Haughton, T. 2007. "When Does the EU Make a Difference? Conditionality and the Accession Process in Central and Eastern Europe." Political Studies Review 5 (2): 233-246.

Herek, G. M. 2007. "Confronting Sexual Stigma and Prejudice: Theory and Practice." Journal of Social Issues 63 (4): 905-925.

Hooghe, M., and C. Meeusen. 2013. "Is Same-Sex Marriage Legislation Related to Attitudes Toward Homosexuality?" Sexuality Research and Social Policy 10 (4): 258-268.

Hughes, J., G. Sasse, and C. Gordon. 2004. "Conditionality and Compliance in the EU's Eastward Enlargement: Regional Policy and the Reform of Sub-National Government." Journal of Common Market Studies 42 (3): 523-551.

Inglehart, R., 1970. "Cognitive Mobilization and European Identity." Comparative Politics, 3(1): 45-70.

Keeling, R., 2006. "The Bologna Process and the Lisbon Research Agenda: the European Commission's expanding role in higher education discourse." European Journal of Education, 41(2): 203-223.

Kelley, J. G. 2006. Ethnic Politics in Europe: The Power of Norms and Incentives. Princeton, USA: Princeton University Press.

Kochenov, D. 2006. “Democracy and Human Rights-Not for Gay People: EU Eastern Enlargement and Its Impact on the Protection of the Rights of Sexual Minorities." Texas Wesleyan Law Review 13: 459-496. 
Kochenov, D. 2008. EU Enlargement and the Failure of Conditionality: Pre-Accession Conditionality in the Fields of Democracy and the Rule of Law. Alphen aan den Rijn, The Netherlands: Kluwer Law International.

Koinova, M. 2011. "Challenging Assumptions of the Enlargement Literature: The Impact of the EU on Human and Minority Rights in Macedonia." Europe-Asia Studies 63 (5): 807-832.

Krizsan, A. 2009. "From Formal Adoption to Enforcement. Post-Accession Shifts in EU Impact on Hungary in the Equality Policy Field." European Integration Online Papers 13 (2).

Krizsan, A., and R. Popa. 2010. "Europeanization in Making Policies Against Domestic Violence in Central and Eastern Europe." Social Politics: International Studies in Gender, State \& Society 17 (3): 379-406.

Kuhar, R. 2013. "In the Name of Hate: Homophobia as a Value." Southeastern Europe 37 (1): 116.

Kuhar, R., and J. Takács, eds. 2007. Beyond the Pink Curtain: Everyday Life of LGBT People in Eastern Europe. Ljubljana: Peace Institute - Institute for Contemporary Social and Political Studies.

Langenkamp, T. J. 2003. "Finding Fundamental Fairness: Protecting the Rights of Homosexuals Under European Union Accession Law." San Diego International Law Journal 4: 437-466.

Lawn, M. and Grek, S., 2012. Europeanizing Education: governing a new policy space. Oxford: Symposium Books Ltd.

Lubbers, M. and Scheepers, P., 2007. "Explanations of Political Euro-Scepticism at the Individual, Regional and National Levels." European Societies, 9(4): 643-669.

Malová, D., and B. Dolný. 2008. "The Eastern Enlargement of the European Union: Challenges to Democracy?" Human Affairs 18 (1): 67-80.

Meyer, J. W. 1977. "The effects of education as an institution." American Journal of Sociology 83 (1): 55-77.

Meyer, J.W., Boli, J., Thomas, G.M. and Ramirez, F.O., 1997. "World Society and the Nation-State." American Journal of Sociology, 103(1): 144-181.

Mole, R. 2011. "Nationality and Sexuality: Homophobic discourse and the 'national threat' in contemporary Latvia." Nations and Nationalism 17 (3): 540-560.

Mole, R. 2016. "Nationalism and Homophobia in Central and Eastern Europe." In The EU Enlargement and Gay Politics: The Impact of Eastern Enlargement on Rights, Activism and Prejudice, edited by K. Slootmaeckers, H. Touquet and P. Vermeersch, 99-122. London: Palgrave Macmillan.

Nancheva, N. 2007. "What Are Norms Good for? Ethnic Minorities on Bulgaria's Way to Europe." Journal of Communist Studies and Transition Politics 23 (3): 371-395.

Norris, P., and R. Inglehart. 2004. Sacred and Secular: Religion and Politics Worldwide. Cambridge: Cambridge University Press.

O'Dwyer, C. 2010. "From Conditionality to Persuasion? Europeanization and the Rights of Sexual Minorities in Post-Accession Poland." Journal of European Integration 32 (3): 229-247.

O'Dwyer, C. 2012. "Does the EU Help or Hinder Gay-Rights Movements in Post-Communist Europe? the Case of Poland." East European Politics 28 (4): 332-352.

O'Dwyer, C., and K. Z. S. Schwartz. 2010. "Minority Rights After EU Enlargement: a Comparison of Antigay Politics in Poland and Latvia." Comparative European Politics 8 (2): 220-243.

Ohlander, J., J. Batalova, and J. Treas. 2005. "Explaining educational influences on attitudes toward homosexual relations." Social Science Research 34 (4): 781-799. 
Olsen, J. P. 2002. "The Many Faces of Europeanization." Journal of Common Market Studies 40 (5): 921-952.

Ostrom, E. 1999. "Institutional Rational Choice: An Assessment of the Institutional Analysis and Development Framework." In Theories of the Policy Process, edited by P. A. Sabatier and C. M. Weible, 21-64. Boulder, CA: Westview Press.

Radaelli, C. M. 2003. "The Europeanization of Public Policy." In The Politics of Europeanization, edited by K. Featherstone and C. M. Radaelli, 27-56. Oxford: Oxford University Press.

Ramirez, F.O., Meyer, J.W. and Lerch, J., 2016. World Society and the Globalization of Educational Policy. In The Handbook of Global Education Policy, edited by K. Mundy, A. Green, B. Lingard and A. Verger, 43-63. Chichester, UK: John Wiley \& Sons, Ltd.

Rasbash, J., C. Charlton, W. J. Browne, M. Healy, and B. Cameron. 2015. MLwiN Version 2.34. Bristol: Centre for Multilevel Modelling, University of Bristol.

Rechel, B. 2008. "What Has Limited the EU's Impact on Minority Rights in Accession Countries?" East European Politics \& Societies 22 (1): 171-191.

Rédai, D. 2012. "Un/Queering the Nation? Gender, Sexuality, Nationality and Homophobia in the Media Discourse on the Violence Against the 2008 Gay Pride in Budapest." Sextures 2 (2): 47-64.

Renkin, H. Z. 2009. "Homophobia and queer belonging in Hungary." Focaal (53):20-37.

Sasse, G. 2008. "The Politics of EU Conditionality: The Norm of Minority Protection During and Beyond EU Accession." Journal of European Public Policy 15 (6): 842-860.

Schimmelfennig, F., and H. Scholtz. 2008. "EU Democracy Promotion in the European Neighbourhood Political Conditionality, Economic Development and Transnational Exchange." European Union Politics 9 (2): 187-215.

Schimmelfennig, F., and U. Sedelmeier. 2004. "Governance by Conditionality: EU Rule Transfer to the Candidate Countries of Central and Eastern Europe." Journal of European Public Policy 11 (4): 661-679.

Schimmelfennig, F., and U. Sedelmeier. 2005. "Introduction: Conceptualizing the Europeanization of Central and Eastern Europe." In The Europeanization of Central and Eastern Europe, edited by U. Sedelmeier, 1-28. Ithaca (New York), USA: Cornell University Press.

Schneider, S.L. and Kogan, I., 2008. "The International Standard Classification of Education 1997: challenges in the application to national data and the implementation in crossnational surveys." In: The International Standard Classification of Education ISCED-An Evaluation of Content and Criterion Validity for European Countries. Mannheim, pp.1346.

Schwellnus, G. 2005. "The Adoption of Non-Discrimination and Minority Protection Rules in Romania, Hungary and Poland." In The Europeanization of Central and Eastern Europe, edited by U. Sedelmeier, 51-70. Ithaca (New York), USA: Cornell University Press.

Sears, J. T. 1997. "Thinking Critically/Intervening Effectively About Heterosexism and Homophobia: A Twenty-Five-Year Research Perspective." In Overcoming Heterosexism and Homophobia: Strategies That Work, edited by J. T. Sears and W. L. Williams, 13-48. New York: Columbia University Press.

Sigel, R. 1965. "Assumptions About the Learning of Political Values." The ANNALS of the American Academy of Political and Social Science 361 (1): 1-9. 
Slootmaeckers, K., 2017. “From 'Strategic Accession' to 'Tactical Europeanisation'?: The Promotion of and Resistance to LGBT Equality in Serbia's European Integration Process." PhD diss., Queen Mary University of London.

Slootmaeckers, K., and J. Lievens. 2014. "Cultural Capital and Attitudes Toward Homosexuals: Exploring the Relation Between Lifestyles and Homonegativity." Journal of Homosexuality 61 (7): 962-979.

Slootmaeckers, K., and I. Sircar. 2018. "Marrying European and Domestic Politics? Investigating the European Dimension of the 2013Croatian Marriage Referendum using a Value-Based Euroscepticism framework." Europe-Asia Studies 70 (3): 321-344.

Slootmaeckers, K., and H. Touquet. 2016. "The Co-Evolution of EU's Eastern Enlargement and LGBT Politics: an Ever Gayer Union?" In The EU Enlargement and Gay Politics: the Impact of Eastern Enlargement on Rights, Activism and Prejudice, edited by K. Slootmaeckers, H. Touquet, and P. Vermeersch, 19-44. London: Palgrave.

Takács, J., and I. Szalma. 2011. "Homophobia and Same-Sex Partnership Legislation in Europe." Equality, Diversity and Inclusion: An International Journal 30 (5): 356-378.

Vachudova, M. A. 2005. Europe undivided: democracy, leverage, and integration after communism. Oxford: Oxford University Press.

Vachudova, M. A. 2008. "Tempered by the EU? Political Parties and Party Systems Before and After Accession." Journal of European Public Policy 15 (6): 861-879.

Vachudova, M. A. 2014. "EU Leverage and National Interests in the Balkans: The Puzzles of Enlargement Ten Years on." Journal of Common Market Studies 52 (1): 122-138.

van den Akker, H., R. van der Ploeg, and P. Scheepers. 2013. "Disapproval of Homosexuality: Comparative Research on Individual and National Determinants of Disapproval of Homosexuality in 20 European Countries." International Journal of Public Opinion Research 25 (1): 64-86.

van der Vleuten, A. 2014. "Transnational LGBTI activism and the European courts: constructing the idea of Europe." In LGBT Activism and the Making of Europe, edited by P. M. Ayoub and D. Paternotte, 119-144. New York: Palgrave Macmillan.

Vermeersch, P. 2005. "EU Enlargement and Immigration Policy in Poland and Slovakia." Communist and Post-Communist Studies 38 (1): 71-88.

Vermeersch, P. 2007. "A Minority at the Border: EU Enlargement and the Ukrainian Minority in Poland.” East European Politics \& Societies 21 (3): 475-502.

Ward, J. 2015. Report on the role of intercultural dialogue, cultural diversity and education in promoting EU fundamental values (2015/2139(INI)). Brussels: European Parliament.

WVS (World Value Survey). 2015. World Value Survey 1981-2014 Longitudinal Aggregate v.20150418, 2015. Madrid, Spain: World Values Survey Association (www.worldvaluessurvey.org). Aggregate File Producer: ASEP/JDS Data Archive.

Zapryanova, G. M., and L. Surzhko-Harned. 2016. "The Effect of Supranational Identity on Cultural Values in Europe." European Political Science Review 8 (4): 547-566. 
Table 1: Results of the Multilevel Analyses

\begin{tabular}{|c|c|c|c|c|c|}
\hline & Model 1 & Model2 & Model 3 & Model 4 & Model 5 \\
\hline \multicolumn{6}{|l|}{ FIXED PART } \\
\hline Constant & $2.915(.295)^{* * *}$ & $3.128(.299)^{* * *}$ & $2.297(1.096)^{*}$ & $5.864(.993)^{* * *}$ & $5.953(.990)^{* * *}$ \\
\hline \multicolumn{6}{|l|}{ Individual level } \\
\hline Female (ref: Male) & & $.360(.014)^{* * *}$ & $.360(.014)^{* * *}$ & $.360(.014)^{* * *}$ & $.357(.014)^{* * *}$ \\
\hline Age (centered on 30) & & $-.023(.000)^{* * *}$ & $-.023(.000)^{* * *}$ & $-.023(.000)^{* * *}$ & $-.023(.000)^{* * *}$ \\
\hline Education (centered on 4) & & $.154(.004)^{* * *}$ & $.154(.004)^{* * *}$ & $.154(.004)^{* * *}$ & $.091(.010)^{* * *}$ \\
\hline \multicolumn{6}{|l|}{ Religion (ref: No Denomination) } \\
\hline Roman Catholic & & $-.424(.028)^{* * *}$ & $-.424(.028)^{* * *}$ & $-.425(.028)^{* * *}$ & $-.421(.028)^{* * *}$ \\
\hline Protestant & & $-.149(.042)^{* * *}$ & $-.149(.042)^{* * *}$ & $-.150(.042)^{* * *}$ & $-.153(.042)^{* * *}$ \\
\hline Orthodox & & $-.162(.024)^{* * *}$ & $-.162(.024)^{* * *}$ & $-.161(.024)^{* * *}$ & $-.164(.024)^{* * *}$ \\
\hline Muslim & & $-.628(.037)^{* * *}$ & $-.628(.037)^{* * *}$ & $-.627(.037)^{* * *}$ & $-.631(.037)^{* * *}$ \\
\hline Other & & $-.400(.062)^{* * *}$ & $-.400(.062)^{* * *}$ & $-.400(.062)^{* * *}$ & $-.399(.062)^{* * *}$ \\
\hline $\begin{array}{l}\text { Religious practice } \\
\text { (centered on 'only on holy days') }\end{array}$ & & $.101(.004)^{* * *}$ & $.101(.004)^{* * *}$ & $.101(.004)^{* * *}$ & $.101(.004)^{* * *}$ \\
\hline \multicolumn{6}{|l|}{ Survey Level } \\
\hline \multicolumn{6}{|l|}{ Accession Status (ref: Outsider) } \\
\hline ENP & & & $.838(1.141)$ & $-.150(.786)$ & $-.216(.784)$ \\
\hline (Potential) Candidate & & & $.910(1.143)$ & $-.117(.793)$ & - .198 (.791) \\
\hline EU Member & & & .831 (1.199) & - . $1711(.869)$ & $-.334(.868)$ \\
\hline Years in EU (centered on 1) & & & $.034(.076)$ & $.019(.076)$ & $.014(.076)$ \\
\hline \multicolumn{6}{|l|}{ Country Level } \\
\hline \multicolumn{6}{|l|}{ Religious Heritage (ref: Protestant) } \\
\hline Catholic & & & & $-.224(.665)$ & $-.208(.663)$ \\
\hline Orthodox & & & & $-1.828(.644)^{* * *}$ & $-1.810(.642)^{* * *}$ \\
\hline Muslim & & & & $-2.353(.741)^{* * *}$ & $-2.339(.739)^{* * *}$ \\
\hline $\begin{array}{r}\text { Communist past } \\
\text { (ref: no communist past) }\end{array}$ & & & & $-1.740(.549)^{* *}$ & $-1.754(.548)^{* * *}$ \\
\hline \multicolumn{6}{|l|}{ Cross-level Interactions } \\
\hline \multicolumn{6}{|l|}{ Accession Status* Education } \\
\hline ENP * Education & & & & & $.034(.012)^{* *}$ \\
\hline (Potential) Candidate $*$ Education & & & & & $.053(.012)^{* * *}$ \\
\hline EU Member * Education & & & & & $.170(.013)^{* * *}$ \\
\hline \multicolumn{6}{|l|}{ RANDOM PART } \\
\hline Country Level: Constant & $2.326(.649) * * *$ & $2.398(.667)^{* * *}$ & $2.331(.650)^{* * *}$ & $.944(.279)^{* * *}$ & $.935(.277)^{* * *}$ \\
\hline Survey level: Constant & $.321(.056)^{* * *}$ & $.308(.054)^{* * *}$ & $.306(.048)^{* * *}$ & $.307(.054)^{* * *}$ & $.312(.055)^{* * *}$ \\
\hline Individual level: Constant & $5.651(.023)^{* * *}$ & $5.217(.022)^{* * *}$ & $5.217(.022)^{* * *}$ & $5.217(.022)^{* * *}$ & $5.205(.022)^{* * *}$ \\
\hline Intra-country correlation & .280 & .342 & .297 & .146 & .145 \\
\hline Intra-survey correlation & .032 & .039 & .039 & .047 & .048 \\
\hline Deviance & 548123.143 & 523276.469 & 523275.117 & 523251.647 & 522999.109 \\
\hline Country level units & 28 & 28 & 28 & 28 & 28 \\
\hline Survey level units & 95 & 95 & 95 & 95 & 95 \\
\hline Individual level units & 119839 & 119839 & 119839 & 119839 & 119839 \\
\hline
\end{tabular}

Note: unstandardized coefficients and standard errors (in brackets) are presented (estimation logarithm: IGLS)

${ }^{*} \mathrm{p}<.05$; ** $\mathrm{p}<.01 ;{ }^{* * *} \mathrm{p}<.001$ 


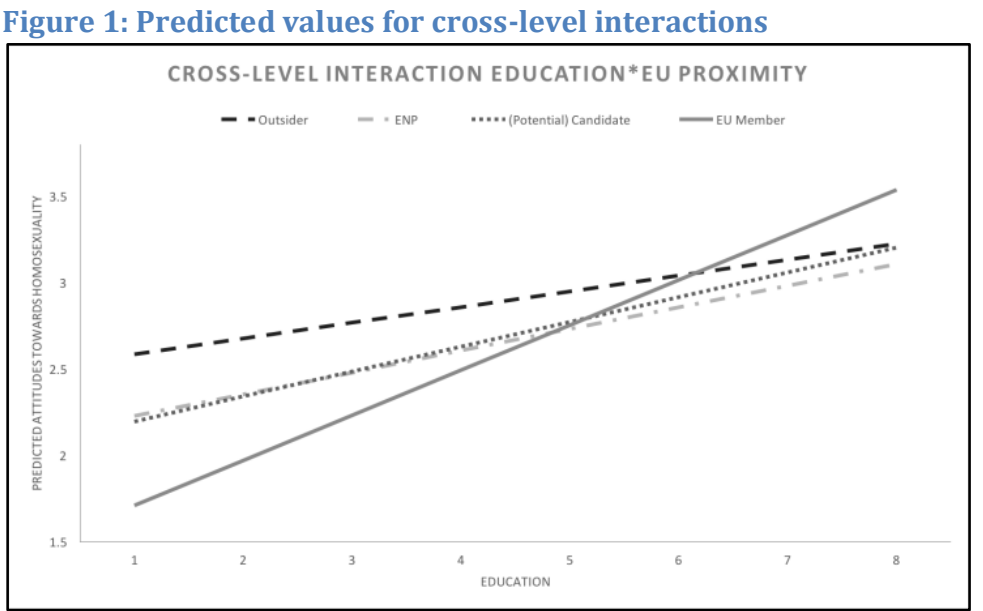




\section{ENDNOTES:}

${ }^{1}$ Although we are aware of and sympathetic to the critical debates regarding the EU fundamental rights identity, it is beyond the scope of this paper to unpack the so-called European values in much detail. In fact, we are here interested in how the EU's investment in the promotion of the values it has identified as its foundation, such as antidiscrimination, can influence third countries' societies.

2 The notion of Europeanization of attitudes is here not used to denote attitudes becoming more European, as this would erase the negative attitudes that exist within the older EU member states. Rather we use the notion to refer to how attitudes change as part of the European integration process. In other words, although the term can be read from an orientalist perspective, the reader should refrain from doing so.

${ }^{3}$ Although this paper deals primarily with lesbian, gay, and bisexual issues, we use the acronym LGBT to be consistent with EU documents and the literature's broader use of the term. To avoid an overload of acronyms, we also use the terms gay and LGBT interchangeably.

${ }^{4}$ For example, van den Akker, van der Ploeg and Scheepers $(2013,1)$ _hypothesize that the 'changing European political structure towards increasingly close cooperation [has] led to the demand for more universal policies'. Others have studied the impact of same-sex marriage legislation on individuals' attitudes towards homosexuality (Hooghe and Meeusen 2013; Takács and Szalma 2011). However, with the exception of a study by Zapryanova and Surzhko-Harned (2016), neither the EU nor the processes of Europeanization that undergird it have been explored as a causal factor on attitudes vis-àvis gay people.

${ }^{5}$ Börzel \& Risse (2007) later clarified the relationship between misfit and adaptational pressure. They refined their argument by stating that misfit only results in adaptational pressure with an active intervention of actors (European or domestic). 
${ }^{6}$ The external incentives approach is by many authors equated with the conditionality principle used by the EU to govern its relations with other countries (see e.g. Glüpker 2013; Koinova 2011; O'Dwyer 2012). While the two concepts are indeed closely related, using them interchangeably conflates the distinct nature of both concepts. While the external incentives model should be regarded as a theoretical framework explaining the impact of the EU on domestic policies, conditionality is a EU tool to influence third countries and thus an example of the causal mechanisms proposed by the external incentives model.

${ }^{7}$ At the level of activism - both supporting gay rights and opposing them - we may expect, of course, that international pressure will shape the issue's politics (see 0’Dwyer 2012), but that is an arena of attitudinal change beyond the one of concern in this paper.

${ }^{8}$ Börzel and Risse (2007) in a later account distinguished processes of persuasion from processes of socialization, arguing that the former follows the logic of communications rather than the logic of appropriateness. However, as persuasion can be translated into the logic of appropriateness, we consider both processes as part of the latter logic.

${ }^{9}$ We want to stress that we are aware of the problematic nature of the notion 'teacher of norms' as used in the literature and do not wish to subscribe to the underlying idea of the EU's exceptionalism of human rights protection and value-based superiority. Although we agree that such critical analysis of EU values and their political nature is needed, it is beyond the scope of this article to do so.

${ }^{10}$ Despite this, most existing studies of the EU's impact on LGBT rights focus on the public policy aspect (Ames 2004; Kochenov 2006; Langenkamp 2003; Slootmaeckers and Touquet 2016).

11 The countries included in data are as follows: Albania, Armenia, Azerbaijan, Bosnia and Herzegovina, Bulgaria, Belarus, Switzerland, Cyprus, Czech Republic, Estonia, Georgia, Croatia, Hungary, Iceland, Lithuania, Latvia, Moldova, Montenegro, Macedonia, Malta, Poland, Romania, Serbia, Russia, Slovenia, Slovakia, Turkey, and Ukraine. The 28 selected countries are those countries that were not part of the EU at the time when LGBT issues 
became officially part of the EU's legal framework (cf. the Amsterdam treaty that introduced anti-discrimination based on sexual orientation into the Treaties). Another reason for excluding the old EU member states is that doing so would distort the analysis due to the continuously observed attitudinal gap between the old and new EU member states. Including the old member states in the analysis would make it impossible to attribute whether the effects observed of EU membership are due to becoming an EU member or the result of pre-existing attitudes.

${ }^{12}$ See also Finlay \& Walther (2003), Herek (2007) and Sears (1997). Although the standard model of attitudes towards homosexuality includes a measure of contact with homosexual, we did not include this measure due to the unavailability of the data.

${ }^{13}$ We have modelled our analysis with a categorical version of the education variables which delivered similar results to those reported. We have decided to report the continuous version of the variable as this version eases the interpretation of the interaction term in model 5.

${ }^{14} \mathrm{We}$ are aware of the measurement issues associated with the ISCED in relation to comparative research (for more details see Schneider and Kogan 2008), but as the best data available and the with our focus on a relative comparison between those with higher levels of education and those with low levels of education, this measure suffices for our analyses. We are not interested in comparing the different categories against each other, but rather look at the additional impact of being on a higher level of education people's attitudes. We are also aware that by treating the variable as a continuous variable we presume a linearity of the educational system, which might not necessarily reflect the reality, but for our explorative purposes this suffice. Moreover, we have run the analyses using a categorical version of the data, with education measured across three categories, which has yielded the same results. We have opted for the continuous version of our model as the results are easier to interpret. 
${ }^{15}$ For proof that the incentive of future integration is not trivial for ENP states, one need only consider the example of Ukraine, whose Maidan protests were initially sparked by the threat of losing its path to future integration with the EU in November 2013.

${ }^{16}$ In East Central Europe such association treaties were referred to as 'Europe Agreements' whereas in the former Yugoslavia they are generally called Stability and Association Agreements.

17 While this operationalization of conditionality might be criticized as too broad-brush, it has the advantage of avoiding the other peril in measuring this variable cross-nationally, i.e. introducing ad hoc assessments of each country case based on a shifting set of contextspecific factors. Recognizing the potentially greater bias of that approach, a country's legal status in the accession process is the standard that other scholars have used in research such as ours. Ayoub (2014), for example, uses application/accession to the EU as a proxy for conditionality in his study of the European integration's influence over policies regarding LGBT people. Probably the most fine-grained operationalization of conditionality in large-n research on EU accession and domestic politics is that of Schimmelfennig and Scholtz (2008, 195-6). They create a typology of accession and potential accession states that incorporates two dimensions: the size and credibility of incentives on offer over the course of the accession process. We have decided against using their more fine-grained operationalization of conditionality, as in our dataset, it would not allow sufficient variation in the variable. Given the no-effect hypothesis for conditionality, we believe a more parsimonious operationalization enables us to test a general effect of the external incentives model. Moreover, practically speaking, they only mention one instance where a significant lag obtained between the size and credibility of incentives, and it regarded Euro-Mediterranean states, not post-communist ones $(2008,196)$. 
${ }^{18}$ As a robustness check we have also included a measure of GDP per capita: however, as this control variable was not significant in our analysis and did not substantively change our results, we have opted to not report this model. 